\title{
The Effectiveness of US Foreign Policies in Diminishing the Diplomatic Power of the PRC (1993-2020)
}

\author{
Jai Chhatwal ${ }^{1}$ and Daniel Schulte ${ }^{\#}$ \\ ${ }^{1}$ Archbishop Mitty High School, San Jose, CA, USA \\ "Mentor
}

\section{ABSTRACT}

Following the market liberalization of the People's Republic of China (PRC), the United States has sought to diminish the PRC's ability to influence the US-backed international order. This paper examines the foreign policy strategies employed by the last four complete US presidential administrations against the change in the diplomatic power of the PRC from 1993-2020 to find which strategy was most effective in achieving this objective. Diplomatic power is measured through the PRC's foreign direct investment (FDI) excluding the US, International Monetary Fund (IMF) voting share, and United Nations General Assembly (UNGA) voting coincidence between the PRC and the US. Change in FDI shows the Trump Administration trade war failed as the PRC's FDI excluding the US increased even when protectionist policies were imposed, as the PRC was able to pivot trade to other nations due to the unilateral nature of the policies. Change in IMF voting share and the PRC's formation of the Asian Infrastructure Investment Bank show that the Obama Administration's attempt to dissuade the PRC into rewriting institutions failed; the Obama Administration achieved advancements on mutual issues of climate, nuclear non-proliferation, and maritime security that supported norms set by the US. UNGA voting coincidence did not show meaningful correlation with US strategy. A successful US foreign policy is one that cooperates on concrete initiatives but not in a flawed manner by giving into PRC demands; when engaging in competition, the US must do so with a coalition of allies to check against PRC diplomatic and trade flexibility.

\section{Introduction}

Following World War II, the United States and the Soviet Union, the remaining superpowers of the world, engaged in a Cold War over the global spread of competing economic and political ideologies. Throughout this period, the United States used a foreign policy strategy of "containment" which emphasized stopping the spread of Soviet ideology rather than reforming the Soviet Union from within. Despite the policy of containment being seen as a general success, following the Cold War, the United States took a different approach in handling the People's Republic of China ("China," "PRC"), a country which had the same competing political and economic ideology that the Soviet Union once did. Beginning with the Clinton Administration and through to the Obama Administration, despite distinct differences between each administration, the US primarily had a stance of "engagement" with China, meaning the US would proactively seek open and free trade with the nation in hopes of integrating it into the existing international institutions that governed world politics. Following the election of Donald Trump, however, this policy changed to one of isolationism and protectionism, where the US took on a more hostile approach to US-China relations that was situated increasingly on trade conflict rather than economic cooperation, as years previous. Due to the increasing prevalence that China plays in the future of the United States' global ambitions due to China's extreme rise in economic power since its market reforms of the late 19th and early 21st century, evaluating the effectiveness of these two contrasting eras of US foreign policy towards China is an opportunity to examine which tools and strategies employed 
by a global hegemon against a rising power are successful in slowing the growth of the diplomatic power of the rising power and/or increasing the strength of the hegemon.

\section{Literature Review}

Due to the recency of the Trump Administration, research that has been published regarding the success and failures of a specific US strategy towards China thus far have oftentimes been evaluated in a vacuum, rather than compared to differing strategies of different eras. Regarding the broadly described policy of engagement that persisted from Clinton to Obama, the consensus in the US is that it failed to meet its primary objective, as the process of integrating China into the global economy did not lead to complete market or political liberalism within China, as proponents of the strategy had hoped [1]. The early movements of the policy of engagement such as pushing for Chinese membership in the WTO allowed China access to global markets without it fully changing its illiberal behavior, which scholars saw as a blow to the United States' proposed international system that is heavily reliant on liberal values, and its diplomatic influence. It is documented that the Bush administration followed this system of engagement, but paid little attention to China in the broader scope of US foreign policy [2]. Following the Clinton and Bush administrations, the Obama administration took a hybrid approach to engagement with increased focus on China in US foreign policy, a strategy dubbed the "pivot to Asia" by the administration. This pivot was characterized by continuing economic cooperation with China, but balancing such a relationship with strengthened alliances, higher military presence, and increased trade and security partnerships in the Pacific region. While the pivot is often credited with resulting in cooperation between China and the US at the Paris Climate Accords, the nuclear nonproliferation regime, maritime law, and more, critics often point to China's increased military involvement in the South China Sea and territorial disputes as evidence that the strategy did not subdue China's strength [3]. Although the Trump Administration's foreign policy also had a strong focus on China, the strategy that the administration took was one of isolationism and protectionism, often characterized by the trade war that spanned nearly the entirety of the administration [4]. Due to the recency of the Trump Administration, there is a lack of substantial amounts of research evaluating the effectiveness and results of this strategy, especially when compared to previous administrations.

\section{Methodology}

This research paper compares different eras of US foreign policy towards China and the resulting change in diplomatic power of China, in order to find which of those foreign policy strategies employed by the United States, as hegemon, was most effective in increasing or decreasing that diplomatic power. To categorize the different eras of US foreign policy towards China, the study examines the change in diplomatic power over time through each year from 1993 (the beginning of the Clinton Administration) to 2020 (the end of the Trump Administration). For the purposes of this study, whichever administration occupied office for the majority of a calendar year will be attributed with that year as a part of their administration. The specific foreign policy strategies of each administration are standardized through two categories. The first is the extent to which China was the focus of an administration's overall foreign policy strategy. This was chosen to fully understand the magnitude and scope of any one strategy compared to another. The second is whether the foreign policy strategy of each administration falls into the bucket of engagement or isolationism. Being the two competing ideologies and strategies that are most discussed in the scholarship and literature base of this topic, such categories are the most relevant. In order to examine the change in diplomatic power of China over time, three categories of comparison are used.

The first category is foreign direct investment (FDI). This category was chosen as FDI is a common metric used to evaluate a nation's diplomatic leverage over another nation through their economic statecraft. In essence, economic power directly influences a nation's diplomatic power and their ability to exert it onto target nations. In specific, the study will examine China's FDI outflows to the United States and China's FDI net outflows excluding 
the United States, in order to find any correlation between foreign policy strategies and fluctuation in China's ability to invest in other nations. The reason that China's FDI outflows to the US are also examined is to ensure that when evaluating China's ability to invest in other nations over time, the net change isn't only representing its change in the US, but also its total diplomatic power, worldwide. China's total FDI net outflows are found through data collected by the International Monetary Fund's Balance of Payments database, which measures the economic transactions by one nation with one or more other nations. China's FDI outflows to the US are found through data collected by the Rhodium Group and the National Committee on US-China Relations, who release China's FDI outflows in all industries to the US specifically, each year [5]-[6]. This value is then subtracted from the aforementioned value of China's total FDI net outflows to find China's FDI net outflows excluding the US for each year.

The second category is voting power in the IMF. Voting power is a metric that shows a nation's raw ability to affect international policy and diplomacy. Out of the major global economic institutions, the IMF was chosen due to its nature of having a voting system that relies on percent shares rather than the one-country-one-vote policy that is standard in other prevalent institutions such as the UN. With such a voting system, it is possible to map out the changes in voting share between the US and China over time, to see how each country's diplomatic power in the institution differed with each era. Data on IMF voting share for each nation was found in the IMF's annual report for each year from 1993-2020 [7]-[34].

The third category is voting coincidence between the US and China in the United Nations General Assembly (UNGA). Since the United States was the sole superpower for much of, if not all of, the 27 year time frame, and the fact that it is the US-supported international order which is at stake, examining how much China's agreement with the US in the UNGA differed over time provides valuable insight into whether or not China fully integrated and accepted this world order, as proponents of engagement thought it would. In essence, diplomatic power includes the ability to influence and leverage other nations into abiding by the agenda favored by the nation exercising its diplomatic power; it also includes the ability to combat such influence on the other side of the matter. Voting coincidence offers insight into how often the two nations agreed and/or cooperated on an issue. Data on voting coincidence percentages between China and the US in the United Nations General Assembly for each year from 1993-2020 was found in a dataset published by Georgetown Professor Erik Voeten [35]-[36]. Examining the three categories of comparison gives a well-rounded view of the changes in different aspects of China's diplomatic power over time as US foreign policy strategies also varied over time.

\section{Results}

Figure 1 plots China's FDI outflow excluding the US and China's FDI outflow to the US every year from 1993-2020. Both scenarios of China's FDI outflow have a similar upward trend until 2016-2017, the beginning of the Trump Administration's trade war, in which both fall dramatically. However, while China's FDI outflow to the US continues to decline in the years following, China's FDI outflow excluding the US rebounds in 2017-2018, before falling once again in 2020 . 


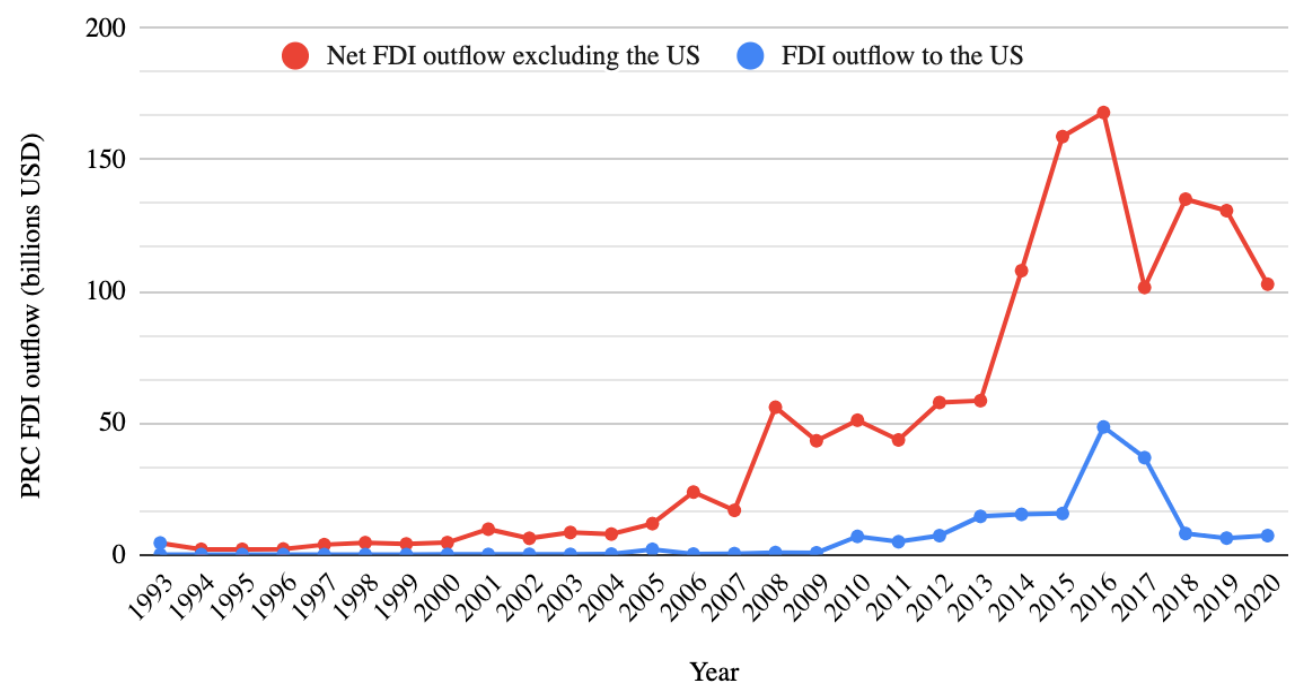

Figure I. PRC FDI NET OUTFLOW EXCLUDING US AND PRC FDI OUTFLOW TO US PER YEAR

Figure 2 plots the US's and China's respective voting shares in the IMF every year from 1993-2020. IMF voting share is determined by a calculation of "a nation's weighted average GDP, openness, economic variability, and international reserves" [37]. The IMF voting share of the US remains seemingly steady, with a gradual decline of less than one percent over the examined time frame. However, the IMF voting share of China has several upward spikes and an upward trend overall. The most significant spike in China's voting share occurred in 2016, when China's voting share rose from $3.81 \%$ to $6.14 \%$. This was due to IMF voting share reforms passed in 2016 that were heavily supported by the Obama Administration. It is important to note that during this time, China formed the Asian Infrastructure Investment Bank, a competitor to the IMF in which China held 26\% of the voting share [38].

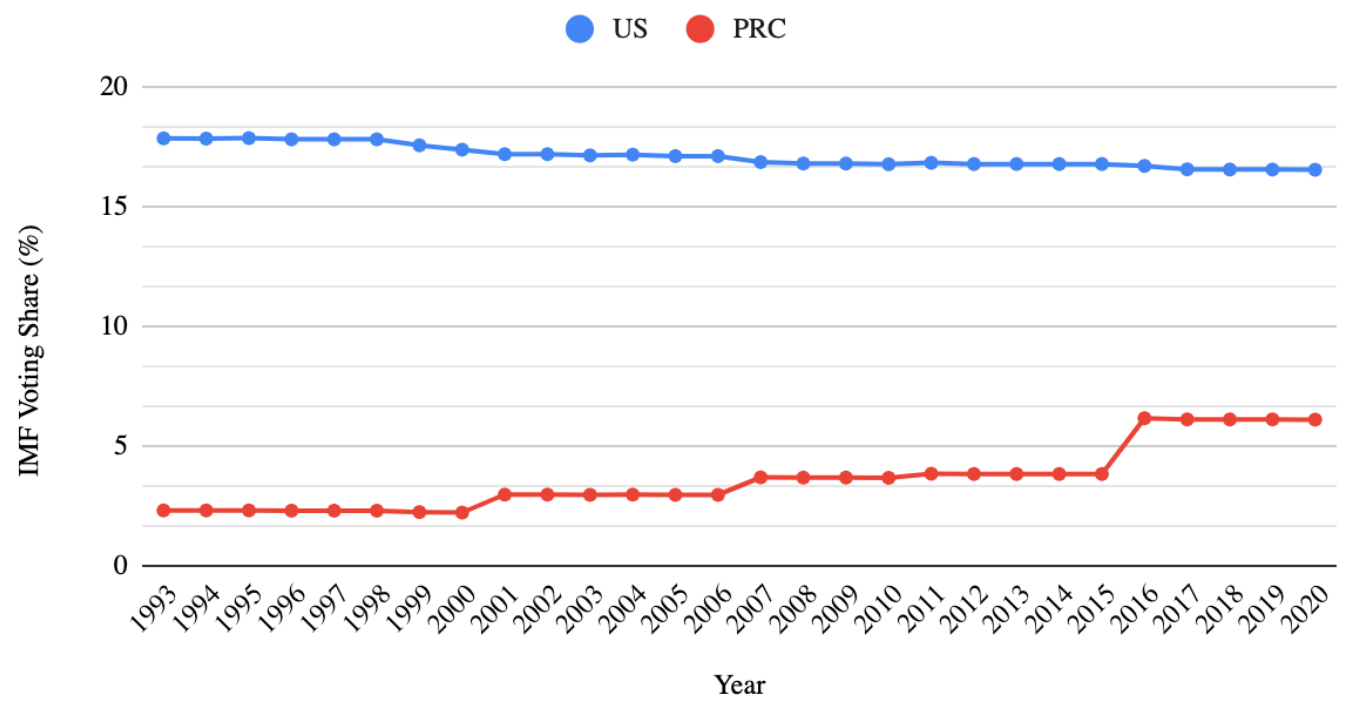

Figure II. US AND PRC IMF VOTING SHARE 
Figure 3 charts the US and China's voting coincidence percentage in the United Nations General Assembly for every year from 1993-2019. Voting coincidence between the two nations gradually rose in the Clinton Administration and began to fall thereafter, until bottoming out at $11 \%$ for the second half of the Bush Administration. Voting coincidence spikes from then on until the end of the first half of the Obama Administration, peaking at $26 \%$ after 2012. In the second half of the Obama Administration, voting coincidence fell to $14 \%$ in 2015 before rising to $21 \%$ in 2016 . It then gradually rose a minimal amount to $23 \%$ in 2017 and $22 \%$ in 2018 , before declining to $18 \%$ in 2020 .

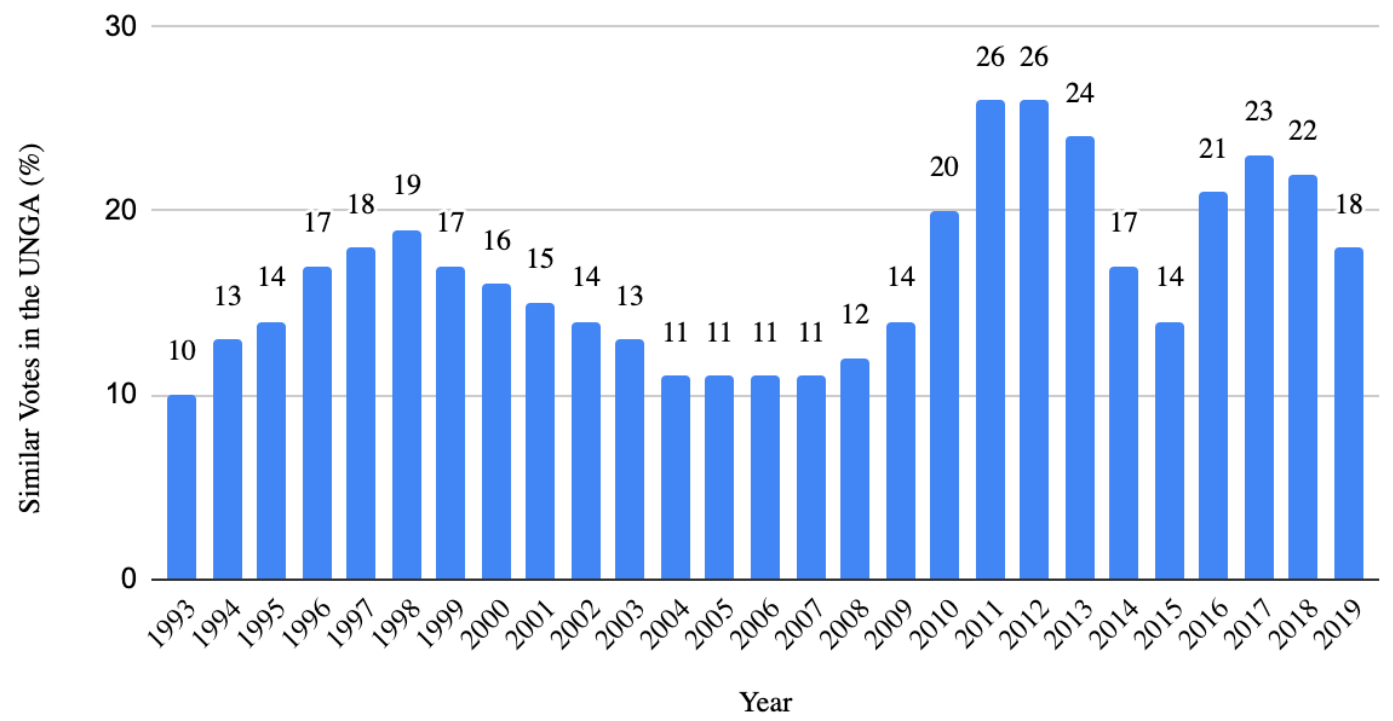

Figure III. PRC \& US VOTING COINCIDENCE IN THE UNITED NATIONS GENERAL ASSEMBLY

\section{Discussion}

As Figure 1 depicts, China's FDI outflows excluding the US first begins to rise following 2001. After the Clinton Administration's push for market liberalism in China, China became a member of the World Trade Organization in 2001. Membership meant that China was to implement market reforms that would make China's economic system more open to foreign actors, thus showing why foreign direct investment rose following this year. It was not until the Obama Administration in 2008, however, did China's FDI outflows excluding the US rise significantly from 16.794 billion USD to 55.974 billion USD. However, China's FDI outflows to the US did not spike to the same effect, meaning it is difficult to prove that the rise in China's FDI outflows to nations excluding the US was due to the Obama Administration's foreign policy strategy, as this strategy included economic engagement with China, which is evidently not yet shown as there is little FDI from China to the US in this year. However, China's FDI outflows excluding the US do begin to mimic their economic involvement in the US through their FDI outflow to the US in later years. For instance, both China's FDI outflow excluding the US and China's FDI outflow to the US peaked in 2016. However, from 2016-2020, China's FDI to the US rapidly declined from 48.48 billion USD to merely 7.2 billion USD. This was primarily due to the trade war initiated by the Trump Administration which imposed tariffs and trade barriers onto China, following the strategy of isolationism and protectionism. While China's FDI outflow excluding the US did also dip in 2017, it rebounded rapidly and continued to rise despite China's FDI to the US continuing to decline, as aforementioned. This means that while the Trump Administration's foreign policy strategy may have been responsible for decreasing China's FDI into the US, it possibly had no effect on China's overall FDI outflow to other nations, meaning China's potential diplomatic leverage through investment in foreign nations persisted in this period. There was another dip in China's FDI outflow excluding the US in 2020, however, this can most likely be attributed to the 
COVID-19 pandemic which resulted in decreased foreign investment positions around the globe [39]. The fact that China's FDI first mimics the United States' somewhat closely but then spikes while the US's sharply declines, points to an important pattern. The US's and China's FDI only began to show completely different trend directions once China's FDI reached an all time high, potentially suggesting that as China becomes larger both economically and diplomatically, it might be harder for the US to influence their actions; China's dependency on the US may be decreasing, a factor that is not reciprocated on the US's end. This discrepancy goes beyond just a sign of a failed trade war. It points to the fact that the US may not be able to control what China does in other spheres of influence, which poses an obstacle to the US's broader foreign policy objective of remaining as the sole superpower and maintaining a rules-based international order led by the values of liberal democracy. Some might say that it is important to note that FDI amounts could have been affected by the trade and economic policies of other nations towards China or China's own policies towards those nations, as well, as the US is not the only nation engaging in trade with China. However, the ability for China to facilitate or block trade and maintain or disrupt economic relations with other nations can be argued to be an aspect of China exercising their diplomatic capacity.

The IMF voting share of the US shown in Figure 2 gradually declines every year from 1993-2020. However, the overall decline is less than one percentage point and thus is not a significant change in the ability for the US to influence the IMF's agenda, as it still holds de facto veto power even at its lowest voting share in the 27 year period. China's IMF voting share over the timeframe tells a different story, however. The nation's voting share gradually increases every year until an extreme spike in 2016. This gradual increase can be attributed to the nation's economic growth, as IMF voting share is directly linked to several aforementioned economic metrics including average weighted GDP, openness, variability, and international reserves. The extreme spike in 2016, however, was due to IMF quota reforms that reallocated voting share from well-developed economies to emerging economies, primarily China [40]. The IMF quota reforms were pushed for by the Obama Administration as part of their broader China foreign policy strategy, in hopes of dissuading China from creating a competitor to the IMF and to further ingrain them in the USsupported international order. While the reforms did evidently result in a larger voting share for China in the IMF, China still went on to form the Asian Infrastructure Investment Bank, where it holds $26 \%$ of the voting share. In this aspect, the Obama Administration's strategy of pushing for IMF voting reforms during this time could be seen as failing to achieve its objective. In summary, China not only increased their diplomatic power through IMF voting share, but also through forming a competitor to the IMF in which they control the majority of the voting share, and in which the US is not a member.

Voting coincidence between the US and China in the UNGA from 1993-2020 does not have any recognizable pattern, as Figure 3 shows. While there are periods where voting coincidence is steadily low, steadily high, gradually increasing, or gradually decreasing, there does seem to be a recognizably consistent change when compared against the foreign policy strategies of the US at any given time. For instance, the Obama Administration was vocal about the US accepting the imminent rise of China [41]. The UNGA voting coincidence at the end of the Obama administration was $21 \%$. In the years following, the Trump Administration would take a more hostile and isolationist approach to China foreign policy that was antagonistic to China's rise. The UNGA voting coincidence in the first year of the Trump Administration was $23 \%$. Despite having a foreign policy that would be more likely to inflame China, the UNGA voting coincidence increased in the first year of the Trump Administration. Even if this anomaly was prescribed to be the overall pattern, it does not hold up in the other various changes in voting coincidence between administrations. This unrecognizable pattern and inability to apply the UNGA voting coincidence trends to different eras of US foreign policy likely shows that UNGA voting coincidence is not particularly reliant on US foreign policy strategy towards China. It is more likely due to the internal politics of the CCP, the ruling party of China. Even then, while such policies that are decided within China can very well be influenced by the foreign policy strategy being exercised by the United States at the time, the voting coincidence between the two nations remained relatively low throughout the 27 year time frame, even when there were stark differences in US policy. Thus, it is difficult to tell if this is the case. It is also important to consider that voting coincidence is reliant on the specific resolutions proposed in the UNGA in a given year, which could have varied significantly in magnitude, importance, divisiveness, etc. from 
year to year. In essence, voting coincidence does not seem to be a suitable metric to determine the extent that China's diplomatic power has changed throughout the examined time frame.

\section{Conclusion}

Diplomatic power is not the only metric that is of importance when examining which US foreign policy strategy would be most effective in maintaining the United States' global standing. However, it is one of the most important and offers insight into how specific strategies employed by the United States have changed China's ability to alter the international order in its favor. The overarching goal of US foreign policy from the Clinton Administration to the Trump Administration, despite their differences in approach, is to maintain a US-backed international system that both upholds the United States and its allies values and ensures the United States' place as the foremost superpower persists. Coming out of a Cold War in which the US focused decades of foreign policy on containing the spread of communism and establishing a world order on the principles of liberal democracy and capitalism, the US was keen to making sure that China, a nation with similar ideals to the Soviet Union, did not pose the same threat to this order in the future. Diplomatic power enhances the ability to influence nations, agendas, and policies within the institutions, inter-governmental organizations, and economic systems that make up this US-supported order. Thus, when crafting a foreign policy strategy to maintain such an order and to hinder China's ability of reshaping that order, it is vital to examine how such a strategy will affect China's overall diplomatic strength and leverage.

The policy of economic engagement that was practiced in the Clinton Administration, Bush Administration, and as a part of the Obama Administration's broader "pivot to Asia" strategy, sought to integrate China so deep into the status quo international order to the point that it would only hurt China if they were to attempt to rewrite such a system. This did not work as intended, as despite being extremely economically interconnected with the United States, China has not accepted the political ideals and beliefs of the United States. This is best seen through the nation's consistently low voting coincidence percentage in the UNGA. Furthermore, the failures of the strategy of pursuing further economic cooperation with China in hopes of them accepting the American system is exemplified by the spike in China's IMF voting share in 2016 after the IMF reforms previously mentioned. Despite the Obama Administration pushing for and successfully implementing this policy that allowed China increased control and participation of an economic institution dominated by the US, China still went on to create the AIIB, a competitor to the US-backed IMF. From this instance, it is certain that the strategy of engagement is not fulfilling its primary objective, as China is attempting to rewrite the international system regardless of having high stakes in the current US-supported system. Such realities turned many towards the opposite extreme of economic engagement, namely isolationism and protectionism. Although the Trump Administration did take such an approach, the results did not match up with the expected goals of the strategy. One of the potential benefits of the Trump Administration's approach was believed to be the ability for the US to leverage their economic interconnectedness with China to weaken them by disentangling this relationship, and thus hurt China's economic prowess overall, and in turn their diplomatic power. However, as the data from Figure 1 showed, while the Trump Administration's trade war tactics did decrease China's FDI into the US, it did not have any apparent effect on their FDI to other nations. In fact, it rose, until the COVID-19 pandemic which affected global FDI. China was still conducting economic activity with other nations regardless of its relations with the US. Essentially, China's ability to exert diplomatic influence through leveraging their investment positions in target countries remained the same or increased, despite the isolationist and protectionist policies of the Trump Administration. The leverage that China holds is access to its markets, which offer low prices and abundant labor among other attractive benefits. By pursuing isolationist and protectionist policies, the US is at risk of being at a disadvantage to other nations, including their own allies, who still have access to China's markets. Hence, China's FDI to other nations remained the same or increased during the period that China's FDI to the US decreased due to the Trump Administration's policies. This instance explains why strong alliances are key to a successful US strategy to mitigate growth of China's diplomatic power. A coordinated effort of competition by a US coalition would stand a much better 
chance than the US alone. However, while this is important, the US must also restrain from pursuing a monolithic strategy that does not take the multiple dimensions of the US-China relationship into account. For instance, as aforementioned, the US and China have cooperated on major issues including climate change and nuclear non-proliferation, which are rooted in crucial values of the rules-based world order that the US has supported. This approach is similar to that of the Obama Administration, which, while making fatal mistakes including the IMF reforms, had the most effective tactics. Rather than taking on the extremes of total engagement as seen in the Clinton and Bush administrations or total hostility and isolation as seen in the Trump Administration, the Obama administration took a midline approach that balanced cooperation with competition. However, even then, the United States must be extremely judicious and strategic in its areas of cooperation, ensuring that it is not "cooperating" simply by giving into Chinese demands or conceding power or influence as the Obama Administration did in 2016 in the IMF. Cooperation must occur in areas that make concrete advancements on issues meaningful to both parties like nuclear non-proliferation, climate, and counterterrorism. Moving forward, if the US wants to form a coherent strategy that is effective in diminishing China's diplomatic power over the US-supported international order, it must be through a nuanced approach that recognizes that cooperation on key issues is possible, and that competition is necessary, but only in a strong coalition of allies.

\section{Acknowledgements}

I would like to thank my mentor Daniel Schulte for guidance in the development of this research paper.

\section{References}

[1] Tan, Yelling. "How the WTO Changed China." Foreign Affairs, 22 June 2021, www.foreignaffairs.com/articles/china/2021-02-16/how-wto-changed-china

[2] Lieberthal, Kenneth G. “The American Pivot to Asia.” Brookings, Brookings Institution, 28 July 2016, www.brookings.edu/articles/the-american-pivot-to-asia/.

[3] Cha, Victor. "The Unfinished Legacy of Obama's Pivot to Asia.” Foreign Policy, 6 Sept. 2016, foreignpolicy.com/2016/09/06/the-unfinished-legacy-of-obamas-pivot-to-asia/.

[4] Allen-Ebrahimian, Bethany. "Special Report: How U.S. Policy toward China Transformed under Trump." Axios, 19 Jan. 2021, www.axios.com/trump-china-policy-special-report-154fa5c2-469d-4238-8d72f0641 abc0dfa.html.

[5] "Foreign Direct Investment, Net Outflows (BoP, Current US\$) - China." The World Bank, data.worldbank.org/indicator/BM.KLT.DINV.CD.WD?locations=CN.

[6] The US-China Investment Hub. Rhodium Group, www.us-china-investment.org/fdi-data.

[7] “IMF Annual Report.” International Monetary Fund, 1993

[8] “IMF Annual Report.” International Monetary Fund, 1994

[9] “IMF Annual Report.” International Monetary Fund, 1995 
[10] “IMF Annual Report.” International Monetary Fund, 1996

[11] “IMF Annual Report.” International Monetary Fund, 1997

[12] “IMF Annual Report.” International Monetary Fund, 1998

[13] “IMF Annual Report.” International Monetary Fund, 1999

[14] "IMF Annual Report.” International Monetary Fund, 2000

[15] “IMF Annual Report.” International Monetary Fund, 2001

[16] “IMF Annual Report.” International Monetary Fund, 2002

[17] “IMF Annual Report.” International Monetary Fund, 2003

[18] “IMF Annual Report.” International Monetary Fund, 2004

[19] “IMF Annual Report.” International Monetary Fund, 2005

[20] “IMF Annual Report.” International Monetary Fund, 2006

[21] “IMF Annual Report.” International Monetary Fund, 2007

[22] “IMF Annual Report.” International Monetary Fund, 2008

[23] “IMF Annual Report.” International Monetary Fund, 2009

[24] “IMF Annual Report.” International Monetary Fund, 2010

[25] “IMF Annual Report.” International Monetary Fund, 2011

[26] “IMF Annual Report.” International Monetary Fund, 2012

[27] “IMF Annual Report.” International Monetary Fund, 2013

[28] “IMF Annual Report.” International Monetary Fund, 2014

[29] “IMF Annual Report.” International Monetary Fund, 2015

[30] “IMF Annual Report.” International Monetary Fund, 2016

[31] “IMF Annual Report.” International Monetary Fund, 2017

[32] “IMF Annual Report.” International Monetary Fund, 2018

[33] “IMF Annual Report.” International Monetary Fund, 2019 
[34] “IMF Annual Report.” International Monetary Fund, 2020

[35] Voeten, Erik; Strezhnev, Anton; Bailey, Michael, 2009, "United Nations General Assembly Voting Data", https://doi.org/10.7910/DVN/LEJUQZ, Harvard Dataverse, V28, UNF:6:dki7hpeRB0FwTFJ00X/TCQ== [fileUNF]

[36] Fu, Yiqin. Who Votes with China, and Who Votes with the U.S. and Europe at the UN? 10 June 2018, yiqinfu.github.io/posts/united-nations-general-assembly./

[37] "IMF Quotas." International Monetary Fund, 2017.

[38] "Members and Prospective Members of the Bank." AIIB, Asian Infrastructure Investment Bank, www.aiib.org/en/about-aiib/governance/members-of-bank/index.html.

[39] UNCTAD. "Global Foreign Direct Investment Fell by 42\% in 2020, Outlook Remains Weak." UNCTAD, 24 Jan. 2021, unctad.org/news/global-foreign-direct-investment-fell-42-2020-outlook-remains-weak.

[40] Truman, Edwin M. "IMF Governance Reform: Better Late than Never." PIIE, Peterson Institute for International Economics, 31 Aug. 2018, www.piie.com/blogs/realtime-economic-issues-watch/imfgovernance-reform-better-late-never.

[41] Condon, Stephanie. “Obama: 'We Welcome China's Rise.”” CBS News, 20 Jan. 2011, www.cbsnews.com/news/obama-we-welcome-chinas-rise/. 